\title{
Extreme and short-lasting sea-level stands structure insular species diversity of a continental-shelf archipelago (Aegean Sea, Greece)
}

\author{
Cyril Hammoud $^{1}$, Konstantinos Kougioumoutzis ${ }^{2}$, Kenneth F. Rijsdijk ${ }^{3}$, Stylianos \\ Simaiakis ${ }^{4}$, Sietze Norder ${ }^{5}$, and E. Emiel Van Loon ${ }^{3}$ \\ ${ }^{1}$ Ghent University \\ ${ }^{2}$ University of Athens \\ ${ }^{3}$ Universiteit van Amsterdam \\ ${ }^{4}$ Natural History Museum - Crete \\ ${ }^{5}$ Universidade de Lisboa
}

April 28, 2020

\begin{abstract}
Recent research in island biogeography has highlighted the important role of late Quaternary sea-level fluctuations in shaping biogeographical patterns in insular systems, but largely focused on volcanic oceanic systems. Through this study we aim to extend this work by investigating the role of late Quaternary sea-level fluctuations in shaping species richness patterns in continental shelf island systems. Focusing on the Aegean archipelago, we first reconstructed the area's geography using published data, under three sea-level stands: 1) current; 2) median over the last nine Glacial-Interglacial cycles; 3) Late Glacial Maximum (LGM). We compiled taxon-island occupancy for angiosperms (70 islands) and centipedes (56 islands). We investigated the impact of present-day and past geographical settings on chorological groups by analysing Island Species-Area Relationships (ISARs) and using Generalized Linear Mixed Models selection based on multiple metrics of goodness-of-fit. Our results confirm that the Aegean's geography has changed dramatically since the LGM, while the median sea-level scenario only modestly differs from the present configuration. Paleogeographical changes largely shaped Aegean plant diversity patterns, and to a lesser degree centipede species richness patterns. The LGM geographic configuration affected both native and endemic species diversity through establishing connections between land-bridge islands and the mainland. Particularly on land-bridge islands we detected supersaturation of native species and stronger underrepresentation of endemics on those same islands. Unlike oceanic islands, where the longer lasting median configuration has ample effect on the current species diversity, the shorter lasting LGM configurations promoted increased connectivity with the mainland counteracting processes promoting endemism. Our study shows that in terms of processes affecting species richness patterns, continental archipelagos differ fundamentally from oceanic systems, highlighting the importance of distinguishing between them while studying biota from the perspective of historical biogeography.
\end{abstract}

\section{Introduction}

Islands are dynamic entities with continuously evolving geographical settings influencing the distribution and genetic evolution of organisms they host. At deep time scales (Ma), an island's ontogeny is controlled by geological processes (Whittaker et al. 2008), while on shorter time scales climatic processes dominate. Climate drives major sea-level fluctuations causing islands to shrink and expand, fragment and merge, or even disappear and emerge (e.g. Simaiakis et al. 2017). Late-Quaternary sea-level changes have left their imprint on insular species diversity patterns (Ali and Aitchison 2014, Rijsdijk et al. 2014, Weigelt et al. 2016, Ávila et al. 2018, 2019, Norder et al. 2019). All of these did however focus on volcanic oceanic islands, or did not make a distinction between oceanic volcanic and continental insular systems and lumped them in their 
analyses (Weigelt et al. 2016, Veron et al. 2019). By disregarding the specifics of continental archipelagos, relevant biogeographical processes are potentially overlooked (Ali 2017, Simaiakis et al. 2017, Whittaker et al. 2017).

Continental shelf islands (sensu Ali 2017) are characterized by sitting on a continental shelf and may include "land-bridge" islands, that were connected to the mainland in the past when sea levels were lower. Another characteristic is the proximity of the mainland often surrounding continental islands (Weigelt and Kreft 2013). The geo-spatial effects of sea-level dynamics on continental island biota have been studied extensively (e.g. Diamond 1972, Cardillo et al. 2008, Itescu et al. 2020). The Aegean archipelago in the Mediterranean Sea is located between the Greek and the Anatolian peninsulas, and is one of the largest archipelagos on Earth (Blondel et al. 2010). Its complex geological history and high environmental heterogeneity contribute to its high biodiversity and endemism, thus rendering an ideal stage for biogeographical studies (Strid 2016). The Aegean islands form a typical continental shelf archipelago with a high geological heterogeneity and numerous land-bridges due to sea-level change. Unsurprisingly, its biogeography has been studied intensively (e.g. Triantis et al. 2018). Although providing crucial biogeographical insights, most studies remain limited in scope by focusing on a single explanatory factor of interest: i.e., by not distinguishing between native and endemic species (Itescu et al. 2020), by considering a single species group or a limited part of the archipelago (e.g. Panitsa et al. 2010). The combined effect of area change, fragmentation and connectivity driven by sea-level changes on insular species diversity has never been investigated for the Aegean archipelago; while we think that such a combined analysis is crucial to interpret the relevant biogeographic processes correctly (see Kougioumoutzis and Tiniakou 2014, Norder et al. 2019). Moreover, the influence of continental landbridge islands on biodiversity patterns in different chorotypes as reflected in multivariate models and Island Species-Area Relationships (ISARs) has never been quantitatively assessed (e.g. Triantis et al. 2008, 2012). Since we have recently quantified the paleogeographic change of islands in the Aegean Sea (Simaiakis et al. 2017) and its biota are well studied, this setting represents an ideal study system to test our hypotheses.

Our aim is to investigate the combined impact on continental insular species diversity of current as well as past island area and connectivity for the Aegean archipelago for two well-studied taxonomic groups, angiosperms and centipedes. Our first hypothesis $\left(\mathrm{H}_{1}\right)$ is that more native species occur on land-bridge islands than on true islands, reflecting the higher establishing rates of native species on land-bridge islands (Simaiakis et al. 2017). Our second hypothesis $\left(\mathrm{H}_{2}\right)$ is that endemism is negatively influenced by landbridge islands, as allopatric speciation is suppressed by repetitive gene-flow from the continents. Our third hypothesis $\left(\mathrm{H}_{3}\right)$ concerns the effect of the duration of the archipelagic configurations as a result of sealevel drop affecting richness patterns. On oceanic islands, the median archipelago configuration could largely explain the endemism richness patterns than the extreme and short-lasting Late Glacial Maximum (LGM) configuration (Norder et al. 2019). Thus on land-bridge islands, the long-lasting median glacial configuration may have largely influenced the species richness patterns, rather than the short lasting LGM extreme state, assuming that short-lasting spatial configurations do not provide the time needed for speciation to occur. To test our hypotheses, we analyse the effects of land-bridge islands on species richness of different endemism levels. We investigate $\mathrm{H}_{3}$ by analysing species richness patterns in relation to two paleogeographical settings: 1) during LGM, and 2) the median sea level during the last glacial-interglacial cycle (Figure 1).

\section{Method}

\section{The Aegean archipelago}

The Aegean is at the convergence of three tectonic plates (Anatolian, African and Eurasian) and has therefore developed major faults systems, resulting in the formation of the South Aegean Volcanic Arc (Higgins 2009). However, even though plate tectonics have strongly shaped the paleo-evolution of the Aegean archipelago, its recent history has been mainly affected by the Pleistocene climatic fluctuations (Sakellariou and Galanidou, 2016). Compared to the magnitude of the geographical changes caused by the sea-level oscillations during the last $150 \mathrm{Ka} \mathrm{BP}$, the importance of the tectonic changes occurring at the same time scale is mostly negligible (Simaiakis et al. 2017). During the LGM (26.5 - 19 ka BP), the global sea level was $~ 135 \mathrm{~m}$ lower than present and locally $>140 \mathrm{~m}$ lower in the Mediterranean (Lambeck and Purcell 2005, Clark et al. 2009, Lambeck et 
al. 2014). Subsequent sea-level rise caused dramatic changes in the Aegean basin with most of the marine transgression observed during 16-11 Ka BP, when sea-level rise rates were 12 m/1 Ka (Simaiakis et al. 2017). This led to a major reduction of total island area by ca. $70 \%$ in the Aegean basin and to a rapid increase of Aegean islands. Large islands $\left(>20 \mathrm{~km}^{2}\right)$ were rapidly shrinking and becoming isolated during that time ( $20 \%$ and $40 \%$ per 1 Kya, respectively - Simaiakis et al. 2017). Islands emerged near the coast of Turkey and Greece that were formerly peninsulas, the western connection between the Peloponnese peninsula and the mainland was lost and the Cycladic paleo-island fragmented into the Cyclades islands group (Figures 1 and 2).

\section{Target organisms}

Angiosperms and centipedes are known for their diversity and endemism rate in the Aegean (Strid 2016, Triantis et al. 2018). Based on biogeographical affinities, different phytogeographical regions have been identified resulting from similar environmental conditions and divergent historical influences (Strid and Tan 1997, Kougioumoutzis et al. 2017).

\section{Species richness data}

We compiled a plant matrix for 70 Aegean islands, including a total of 3246 native vascular plant taxa (species and subspecies). The angiosperms are a well-studied group in the Aegean, and we compiled data on five chorotypes and two combined chorotypes (Figure 1) based on an extensive bibliographical database for the Aegean archipelago (see Appendix S1 in Kougioumoutzis et al. 2017). The 'native non-endemics', here termed 'natives', are a widely spread taxonomic group that occur both on the Greek Islands and on the mainland across the Mediterranean (2673 taxa).

The 'Greek endemics' are species exclusively occurring both on the Greek mainland and the Aegean islands (689 Taxa). The 'Aegean endemics' (AE) are found on multiple islands but not on the mainland (91 taxa). The 'phyto-region endemics' (PE) are restricted to one or multiple islands located within the same Aegean phytogeographical region sensuStrid and Tan (1997 - 384 taxa). Finally, the single island endemics (SIEs), are endemics occurring exclusively on one of the Aegean islands (292 taxa). We also combined chorotypes to compare general trends of endemics with non-endemics and to assess trends in similar multiple endemics chorotypes. We combined both phyto-region and Aegean endemics to form 'multiple islands endemics' (MIEs) sensu stricto (450 taxa). We also combined all endemic chorotypes into an "all-endemics group" ( $\mathrm{E}_{\mathrm{ALL}}$ ).

A similar matrix was compiled for 56 Aegean islands and 70 centipedes (see Simaiakis et al. 2004, 2005).

Two chorotypes were distinguished: 'native' and 'endemics' ( 65 and 5 species, respectively). The data set for single island endemics of centipedes was too small for a statistical assessment.

\section{Paleo-island morphometry}

To test our hypotheses, we estimated the past insular areas and distances to the mainland in order to use these metrics as predictors of current species diversity. Herein, we were interested in the difference between the present-day geographical setting, the situation during the LGM and the situation under the median sea level over the last nine glacial-interglacial cycles (MSL - Norder et al. 2019). Hence, besides the present-day configuration of the Aegean islands, we used the work by Simaiakis et al. (2017 - Supplementary Material Appendix 1) for paleogeographical configurations. To investigate the biogeographical effects of past fragmentation from the mainland, we classified islands into two different groups: those that remained isolated from the mainland, referred to as "true islands" versus those with an episodic connection to the mainland during the LGM ("LGM land-bridge islands") or at median sea level ("median land-bridge islands" - Simaiakis et al. 2017).

\section{Inferential analysis}

ISARs were fitted using the logarithmic transformation of the Arrhenius (1921) power model. We compared the models using adjusted- $\mathrm{R}^{2}$ values as a measure of their goodness-of-fit. As the models have the same number of fitted parameters, the $\mathrm{R}^{2}$ are directly comparable, without modification (Triantis et al. 2005). 
We also calculated the mean area-adjusted species richness for all angiosperm and centipede chorotypes and distinguished between true and land-bridge islands. To investigate the impact of past geographical changes on current diversity, we compared the performance of three alternative generalized linear mixed models (GLMMs) in explaining species richness. The models correspond to the geographical setting of the Aegean at three stages: present-day, LGM and MSL. The present-day model (null model) consisted of present-day area, distance to the mainland, and spatial autocorrelation as fixed effect and phytogeographical province as random effect. The models for the paleogeographical settings (LGM or median) included the same predictors as the null model plus the following metrics of change in insular geography compared to the present-day setting: area loss, increase of distance to the mainland and whether an island was a land-bridge island or remained a true island. We fitted these three sets of predictors on the following response variables: the species richness of all six chorotypes of angiosperms, the total angiosperm species richness, total angiosperm endemics richness and total centipede species richness. All models were fitted using a log-link function and Poisson distribution for the error term (lmerTest package, Kuznetsova et al. 2017). All variables with p-values $>0.1$ were excluded from the models to obtain a set of "suggestive, but inconclusive" predictors (Murtaugh 2014) before refitting with the remaining variables. Multicollinearity was addressed by computing the variance inflation factors (VIF) of the predictors and removing variables with VIF $>2.5$ (Dormann et al. 2013). Finally, we identified the models that provided most explanatory potential using multiple measures of goodness-of-fit: the corrected Akaike Information Criterion (AICc), Bayesian Information Criterion (BIC), conditional $\left(\mathrm{R}^{2} \mathrm{c}\right.$ ) and marginal $\left(\mathrm{R}^{2} \mathrm{~m}\right) \mathrm{R}^{2}$ (MuMIn package, Barton 2009) and leave-one-out cross-validated (loocv) pseudo- $\mathrm{R}^{2}$. All analyses were performed in $\mathrm{R}$ version 3.4.2 ( $\mathrm{R}$ core team 2018). Crete was excluded from all models fitted as diagnostic residual plots of residuals vs. leverage systematically designated it as an outlier (not shown). Because of the low number of endemic centipede species and their over-dispersion in the islets adjacent to Crete, we restrained our analysis of the centipede fauna to native centipede diversity.

\section{Results}

Geographical changes in the Aegean

Our reconstructions show that the geography of the Aegean archipelago changed dramatically throughout the last climatic cycle of the Quaternary (Figure 2). The current configuration and the LGM setting represent two extremes of the sea-level fluctuations (highest now, lowest during the LGM). Islands' morphometry and isolation varied correspondingly: Island areas achieved a maximum size during the LGM and are at their minimal size now, with intermediate values at the MSL, while isolation was minimal in the LGM (Supplementary Material Appendix 2 Table A2.1). Fewer islands were connected to the mainland during the MSL compared to the LGM (Supplementary Material Appendix 2 Table A2.2).

\section{Explorative and inferential analyses of species richness}

The ISAR power function model explained a higher proportion of variance on true islands than on landbridge islands; the z-curve followed a similar trend, apart from the Greek and phytogeographical endemics (Table 1). Land-bridge islands appear to host more native taxa than true islands, while the opposite trend is observed regarding endemic taxa (Figure 3).

\section{Models}

The proportion of variance explained was generally high for all models (16-83\% - Table 2) and was overall greater for angiosperms than centipedes. Biogeographical affinity explained a large proportion of variance for all endemic categories (13-67\% - Table 2), but not for the native angiosperms and centipedes (Table 2). Area was the most important predictor in almost all models (Table 2; Figure 4). LGM-related variables emerged as important predictors for all angiosperm chorotypes, except for the Greek endemics and the SIEs (Table 2; Figure 4). MSL area loss had an insignificant negative effect on SIE richness patterns (Table 2; Figure 4).

\section{Discussion}

Species richness patterns 
Late Quaternary sea-level changes have left their mark on island species richness patterns (e.g. Weigelt et al. 2016, Norder et al. 2019), following theoretical expectations (Fernández-Palacios et al. 2015). Recently, the question arose whether LGM paleogeographical configurations or those more representative of the Pleistocene better explain endemic species richness (Norder et al. 2019). It seems that on oceanic islands the intermediate sea-level configuration shapes SIE and MIE diversity patterns (Norder et al. 2019). Our study aimed to investigate the possibility that different patterns might be observed on continental islands, which have not been investigated with regard to these questions so far.

Our power-function model had high predictive capacity (Table 2) and our results are in line with Kreft et al. (2008), as well as the with values reported for several Greek island phytogeographical regions (e.g. Kagiampaki et al. 2011, Kougioumoutzis and Tiniakou 2014, Valli et al. 2019: 82-95\%). Our results corroborate $\mathrm{H}_{1}$ and $\mathrm{H}_{2}$ : land-bridge islands host more native non-endemic taxa, yet significantly fewer endemics (Figure 3). This pattern is also reflected in ISAR z-values (Table 1; Appendix 3). The overall angiosperm $\mathrm{z}$-value $(\mathrm{z}=0.329)$ falls within the range for continental shelf settings (Triantis et al. 2012) and is similar to that of the East Aegean islands $(\mathrm{z}=0.326$; Panitsa et al. 2010), which are land-bridge islands. Aegean land-bridge islands host significantly more native taxa and fewer endemics than true islands, thus implying that the former were probably supersaturated in native taxa, after sea levels dropped. This could result from the high geospatial connectivity states prevailing during the Quaternary glacial sea-level low-stand periods, promoting continuous influx of native taxa (e.g., Panitsa et al. 2018). These biota are currently experiencing a relaxation period and have not reached equilibrium (Simaiakis et al. 2017), a pattern reflected on their endemic ISARs as well (low $\mathrm{R}^{2}$ values - Table 1 ). The opposite trend is observed for all the endemic chorotypes - being more pronounced for SIEs - as the ISAR slope is steeper for the true islands (Appendix 3), confirming $\mathrm{H}_{2}$. Nevertheless, the SIEs ISAR slope is significantly lower than reported from oceanic islands $(\mathrm{z}=0.8$; Triantis et al. 2008), pointing to a state of endemic underrepresentation on continental islands. The frequent reconnections with the mainland during the glacial-interglacial cycles, enabled gene flow between previously isolated insular and continental source populations repeatedly re-established, thus hampering speciation and consequently leading to lower endemism levels and species numbers (Whittaker and Fernández-Palacios 2007).

\section{Intermediate Pleistocene configurations and island fragmentation}

The long-lasting MSL configuration does not seem to have shaped continental island species richness patterns $\left(\mathrm{H}_{3}\right)$. LGM configuration on the other hand, emerged as a major predictor for both native and endemic species richness (Figure 4). The maximum, yet short-lasting connectivity achieved during the LGM (Figure 2; Sakellariou and Galanidou 2016) has negatively affected endemic diversity (except SIEs), suggesting that the LGM spatial configuration of the Aegean archipelago has left its imprint on species' distribution, richness and evolutionary patterns (e.g., Poulakakis et al. 2015, Kougioumoutzis et al. 2017). Quaternary fragmentation, as well as the repeated and rapid paleo-islands fragmentation due to sea-level oscillations during 20-11 Ka may be responsible for the observed continental MIE patterns, apart from the dramatic island area-loss since the LGM $(>70 \%)$. This process affects island species richness irrespective of area, via passive dispersal. Island-fragmentation seems more prominent on continental rather than on oceanic MIEs. The contrast in high numbers of islands shared by continental MIEs and the low number of islands shared by oceanic islands MIEs can be simply explained by much lower numbers of paleo-islands in oceanic island settings that became fragmented by Pleistocene sea-level oscillations (Norder et al. 2018) compared to what we see in continental settings (Simaiakis et al. 2017). As a result, Aegean MIEs had typically a much larger distribution on larger pre-existing paleo-islands, sometimes even reaching beyond the Quaternary (Rechinger 1943, Rechinger and Rechinger-Moser 1951, Runemark 1969, 1971, Greuter 1971, Snogerup 1971, Strid 1972). This may indicate that Aegean MIEs may have a pre-Tertiary imprint of the paleogeography, when the sea level was as high as during the Quaternary interglacials and these land-bridge islands were true islands. Those paleo-islands fragmented earlier than the Quaternary by geological processes over millions of years (Creutzburg 1966, Dermitzakis 1990). For instance, pre-Pleistocene paleo-connections existed between the (Pleistocene) true islands Kythira, Crete, Karpathos and Rodos (Dermitzakis 1990, Schüle 1993) or between the south-central Cyclades and Kriti (Kapsimalis et al. 2009, Sakellariou and Galanidou 2016). Pleistocene sea-level oscillations 
further fragmented the geologically earlier fragmented populations even more, as for instance on the Cyclades (Simaiakis et al. 2017). Both geological pre-Pleistocene breaking up of islands and Pleistocene sea-level rise induced island fragmentation led to the fragmentation of paleo-endemics that perhaps once were single island endemics on larger pre-existing islands. In topographically complex islands, some of the old MIEs probably gave rise to mostly neo-endemic SIEs through allopatric speciation (e.g. Runemark 1969, 1971, Bittkau and Comes 2009, Jaros et al. 2018). For these reasons, the usual classification of endemics into SIEs or MIEs would make little sense in a continental-shelf system that is both fragmented by regionally different geological events and Pleistocene sea-level oscillations and where dispersal distances between islands are short and past land-connections were frequent. This highlights the importance of working with subsets of species data that reflect the common evolutionary history of the species included.

Continental SIEs however, are unaffected by past configurations (Table 2; Figure 4), contrary to oceanic SIEs which are driven by MSL configurations (Norder et al. 2019). Oceanic island speciation and endemism are elevated due to the MSL long-lasting, large island size (Norder et al. 2019). Meanwhile, on continental islands large island size was achieved during the LGM as a result of maximum connectivity. This enabled increased gene-flow, thus leading to lower speciation and endemism levels (e.g. Panitsa et al. 2018 and references therein). Most Aegean SIEs occur on Crete and then on 25 other islands, most of them (18 islands) containing only one SIE. Plant diversification and speciation in the Aegean is mainly driven by random genetic drift (Georghiou and Delipetrou 2010 and references therein) and active species differentiation took place inside numerous islands (Cardona and Cotandriopoulos 1978). Several Aegean endemics occupy precipitous limestone cliffs, which are remnants of mountaintops that were most pronounced during the LGM, when sea levels were up to $140 \mathrm{~m}$ lower. These cliffs were virtually inaccessible even to the dominant components of cliff communities in the adjacent mainland regions (e.g., Inula verbascifolia group and Campanula subsect.Quinqueloculares ) and served as refugia during the Quaternary glaciations, leading to high genetic differentiation and systematic isolation (e.g., Linum arboreum - Thomson 2005). Only three islands host more than 10 SIEs: Evvia, Samos and Samothraki, which all were land-bridge islands since LGM; Samos was a land-bridge island also during median sea levels. These three islands are mountainous and topographically most pronounced, suggesting that topography plays an additional important role in SIE formation and ecological isolation might have driven speciation (e.g. Kallimanis et al. 2010, Trigas et al. 2013, Steinbauer et al. 2013, 2016). The topographic complexity and geodiversity of these islands may also explain the ISAR SIE pattern. The large number of SIEs occurring in Crete is due to its large size, long isolation, high topographical and environmental heterogeneity, as well as its paleogeographical history (Greuter 1972, 1975, Kagiampaki et al. 2011, Médail 2017).

\section{Centipede diversity}

The remarkably low z-value $(<0.18)$ for all centipedes, even lower than reported for vertebrates (Triantis et al. 2008), is probably explained by low degrees of island isolation fitting with the paleogeography of the Aegean, where most of the islands were recently connected either with continental Greece or the Anatolian peninsula. Although Crete became permanently isolated approximately 9 Mya from Anatolia to the east and 5.5 Mya from mainland Greece from the west, the majority of the islands were isolated less than 21 Kya (Perissoratis and Conispoliatis 2003). The absence of endemic centipedes on land-bridge islands confirms our $\mathrm{H}_{2}$, namely that endemism is demoted on land-bridge islands. For native centipedes, higher z-values and $\mathrm{R}^{2}$ values on true islands compared to land-bridge islands support higher levels of native centipede diversity. This counterintuitive trend is most likely a reflection of suitable cryptozoic habitat types on true islands, the change of occurring on these islands increases with island size. All centipedes are predatory soil animals with distinguished dispersal abilities that show ecological preferences to microhabitats such as leaf litter in the upper soil layer, into cavities in the deeper soil layers as well as under stones and barks (Voigtländer 2011). Because of their cryptozoic life-style most centipede species seem to be more insensitive than most angiosperms to geographical changes caused by sea-level rise in the Aegean archipelago. This could justify the less significant role of paleogeography (LGM and median) in the diversity patterns of the centipedes in the Aegean archipelago. One of the most exceptional features of certain centipede species, particularly geophilomorphs, is that they reside on the sea shore between tidemarks (e.g. Pachymerium ferrugineum , 
Tuoba poseidonis, see Lewis 1981). Thus, periods of high rates of sea-level rise such as following the LGM might have caused fast extinctions in these taxa, leading faster to a new equilibrium. Centipede species richness is therefore mainly determined by present-day geography (Table 1), with area and distance from mainland being the most significant variables for total species richness, meaning that centipedes tend to be faunistically relaxed. However, Kastelorizo, Ro and Stroggyli are supersaturated with centipedes as a result of their connection to Turkey during the LGM. Kastelorizo for example is about 800 times smaller than Crete but hosts 19 species of centipedes - roughly half the richness found in Crete.

\section{Biogeographical affinity}

Biogeographical affinity (i.e., the random effect in our models) explained only a small fraction of the variance for the native taxa. This can be attributed to the fact that a large portion $\left({ }^{\sim} 40 \%\right)$ of the present Aegean flora has reached the Aegean islands as a result of human action in prehistoric or early historic times (Greuter 1979). The presence of these naturally or artificially distance-insensitive species clearly justifies the less significant role of biogeographical affinity in the diversity patterns of the native plant taxa occurring in the Aegean archipelago. On the other hand, the largest proportion of variance for all the endemic species richness metrics is attributed to biogeographical affinity. This is in line with previous studies stating that in the Aegean, bioregionalization is primarily a result of the region's complex paleogeographical history (Kougioumoutzis et al. 2017) This is also due the high proportion of narrowly-ranged species and consequently of high species turnover in Aegean island plant communities: nearly $\sim 45 \%$ of the endemic taxa occurring in the Aegean are SIEs, the vast majority of which occur in Crete and Evvia (Panitsa et al. 2018). Other factors such as climate and geodiversity probably play an important role in shaping current endemic diversity patterns in the Aegean, as is actually the case for the central (Kougioumoutzis and Tiniakou 2014), eastern (Panitsa et al. 2010, Panitsa and Tzanoudakis 2010) and southern (Kagiampaki et al. 2011) Aegean islands. In addition, favourable climatic conditions most probably permitted a relict flora to persist in the southern (i.e., Crete, Karpathos, Rodos) and eastern (e.g., Ikaria: Christodoulakis 1996a, b) Aegean archipelago (Runemark 1969, 1971). In topographically complex islands, some of the old MIEs formed neo-endemic SIEs through allopatric speciation (Runemark 1969, 1971, Bittkau and Comes 2005, 2009, Comes et al. 2008, Jaros et al. 2018). Geographical isolation through sea-level oscillations may have supported the recent diversification of neo-endemic species, especially in the central Aegean where several non-adaptive radiations occurred (e.g. Campanula , Nigella , Erysimum - e.g. Comes et al. 2008, Jaros et al. 2018), as a result of a turbulent and labyrinthine sequence of island-splitting events in a short time-period, since most of the geographic configuration change occurred during marine transgression in the Aegean within 5000 years between 16 and $11 \mathrm{Ka}$ BP (Simaiakis et al. 2017). Especially when considering the repetitive character of fragmentation over the last $2 \mathrm{My}$, the fragmented and disconnected state existed during every glacial-interglacial interval for $\sim 20 \mathrm{ka}$ disrupting the longer lasting glacially connected state, leading to cumulative genetic divergence between populations (Aguilée et al. 2009). One prominent example for this is the differentiation of the Nigella arvensis species complex which is due to non-adaptive radiation and random genetic drift as a result of several vicariant events during the Pliocene/Pleistocene (Bittkau and Comes 2005, Bittkau and Comes 2009).

\section{Continental-shelf and oceanic archipelagos}

The geographical setting of the LGM is an extreme configuration that was represented only sporadically and for short time-periods throughout the Pleistocene, with only $2 \%$ of the last $800 \mathrm{Ka}$ BP estimated to have a similarly low sea level (Norder et al. 2019). Therefore, the duration of these episodes may have been too short to have had a significant impact on the diversity and composition of insular biota on oceanic islands (Porter 1989, Heaney et al. 2013, Norder et al. 2019). Our results show however, that in a continentalshelf archipelago, most of the Aegean angiosperm endemic richness patterns are best explained by LGM configurations, and the richness of native non-endemic angiosperm species and to a lesser extent, centipedes still shows an impact of the same configuration. We explain this as the result of extreme connectivity that was achieved during the LGM between the expanded Aegean true islands, land-bridge islands and the surrounding continental land mass. This connectivity with the mainland, even though short-lasting, 
promoted both conditions of native supersaturation on islands that were once connected to the mainland and conditions of lower endemism levels in the Aegean island biota. The ISAR z-values for total angiosperm richness fall into the z-value range for continental island settings. On the other hand, the endemic richness z-values are much lower than those on oceanic islands, pointing to reduced endemism on continental islands. The mean adjusted species richness of natives on land-bridge islands point to oversaturation of natives on land-bridge islands. We also observed that the high degree of Aegean island fragmentation by Pleistocene sea-level oscillations led to MIEs sharing much more islands $(>5)$ than is observed for oceanic archipelagos. The multiple island angiosperm endemism manifest in the Aegean today is indeed largely shaped by the fragmentation of large landmasses into smaller islands by the present high sea level. Lastly, we noted that deep time pre Quaternary geological island fragmentation left a distinct signature on endemism. Native species supersaturation and reduced endemism are thus essential processes that distinguish continental and oceanic island from the perspective of historical biogeography. It remains to be tested in how far maximum connectivity conditions are exclusively related to the lowest short-lasting sea-level stand, or whether for most biota maximum connectivity was reached earlier and lasted longer than the LGM. Clearly this depends on the geometry and depth of the basin under study, influencing the sea-level thresholds at which island area and connectedness change significantly (Norder et al. 2019). We can conclude there is a crucial difference between oceanic and continental islands: the rate of area loss, as well as the degree of fragmentation, is far greater in continental islands and as such, the recent sea-level changes might have influenced more intensely their biota mediated through increased connectivity with the nearby mainland during marine low-stands. Moreover, speciation as a result of isolation and ecological speciation (through vacant niche space) is the main driver of species richness on oceanic islands, in contrast to continental islands where supersaturation and species disequilibria due to greater extinction debt are seen as prevalent. Single island endemism is generally supressed on continental islands, and when endemism does manifest, it is then the result of higher variability in topography or geodiversity offered by the continental islands (e.g. Panitsa et al. 2010).

\section{Conclusions}

The Aegean continental islands were separated from the mainland for a very long period of time $(>2.6$ Ma) thus promoting endemism; the extreme and recent paleo-configurations of high connectivity with the mainland that started with the onset of the Quaternary greatly affected their species richness and speciation patterns. These connections with the mainland manifested as "shocks" of sorts, when isolated islands became connected with the mainland (Sondaar and Van der Geer 2005). We hypothesise that increasing lower sea levels over the Quaternary period led to migration waves of continental species to ever more continental islands disrupting allopatric evolutionary processes, induced extinctions in single island endemic species, ultimately leading to signals of endemic underrepresentation and native supersaturation tuned to the most extreme (LGM) configurations prevalent at the end of the Pleistocene. We noted for some multiple endemic chorotypes, the high z-values on land-bridge islands and a dependency on present day distance, which may reflect a relict response to the pre-Quaternary conditions, when these land-bridge islands still were true islands. Continental systems therefore hold ample evidence of the effect of paleogeography on the species richness, speciation and biogeographical patterns of the Aegean islands. The noted principal differences in geographic and evolutionary mechanisms between oceanic and continental islands make statistical assessments of endemic species data of combined oceanic and continental islands fundamentally problematic and studies involving both systems should explicitly incorporate their differences in statistical models.

\section{Declarations}

The authors declare no conflicts of interest. $\mathrm{CH}$ was partially funded by a FWO research grant (ref. 11C5219N) during this work. SJN received funding from the Portuguese National Funds, through Fundação para a Ciência e a Tecnologia (FCT), within the project UID/BIA/00329/2013 and the Research Fellowship $\mathrm{PD} / \mathrm{BD} / 114380 / 2016$.

\section{Data Accessibility Statement}

All relevant GIS files, species matrixes and R scripts will be made available using Dryad data repository. 


\section{Bibliography}

Aguilée, R., Claessen D., Lambert A. 2009. Allele fixation in a dynamic metapopulation: founder effects vs refuge effects. - Th. Pop. Biol. 76: 105-117.

Ali, J.R. 2016 Islands as biological substrates: classification of the biological assemblage components and the physical island types. - J. Biogeogr. 44: 984-994.

Ali, J. R., Aitchison, J. C. 2014. Exploring the combined role of eustasy and oceanic island thermal subsidence in shaping biodiversity on the Galápagos. - J. Biogeogr. 41: 1227-1241.

Arrhenius, O. 1921. Species and area. - J. of Ecology 9: 95-99.

Ávila, S. P., Cordeiro, R., Madeira, P., Silva, L., Medeiros, A., Rebelo, A. C., Johnson, M. E. 2018. Global change impacts on large-scale biogeographic patterns of marine organisms on Atlantic oceanic islands. Marine Pol. Bul. 126: 101-112.

Ávila, S. P., Melo, C., Berning, B., Nuno, S., Quartau, R., Rijsdijk, K. F., Johnson, M. E. 2019. Towards a 'Sea-Level Sensitive' dynamic model: impact of island ontogeny and glacio-eustasy on global patterns of marine island biogeography. - Biol. Rev. Camb. Philos. Soc. 94: 1116-1142.

Barton, K. 2017. Mu-MIn: Multi-model inference. - R Package Version 0.12.2/r18.

Bittkau, C., Comes, H. P. 2005. Evolutionary processes in a continental island system: Molecular phylogeography of the Aegean Nigella arvensis alliance (Ranunculaceae) inferred from chloroplast DNA. - Mol. Ecology 14: 4065-4083.

Bittkau, C., Comes, H. P. 2009. Molecular inference of a Late Pleistocene diversification shift in Nigella s. lat. (Ranunculaceae) resulting from increased speciation in the Aegean archipelago. - J. Biogeogr., 36: 1346-1360.

Blondel, J., Aronson, J., Bodiou, J.-Y,. Boeuf, G. 2010. The Mediterranean Region. Biological Diversity in Space and Time. - Oxford Univ. Press Inc.

Cardillo, M., Gittleman, J., Purvis, A. 2008. Global patterns in the phylogenetic structure of island mammal assemblages. - Proc. Biol. Sci. 275: 1549-1556.

Cardona, M.A. and Cotandriopoulos, J. 1978, L'endémisme dans les flores insulaires Méditerranéennes. Mediterranea $2: 49-77$.

Christodoulakis, D. 1996. The phytogeographical distribution patterns of the flora of Ikaria (E. Aegean, Greece) within the E. Mediterranean. - Flora 191: 393 - 399.

Christodoulakis, D. 1996. The E. Aegean flora of Ikaria (Greece islands). - Phyton 36: 63-91.

Clark, P., Dyke, A., Shakun J., Carlson, A., Clark, J., Wohlfarth, B., Mitrovica, J., Hostetler, S., McCabe, M. 2009. The Last Glacial Maximum. - Science 325: 710-714.

Comes, H. P., Tribsch, A., Bittkau, C. 2008. Plant speciation in continental island floras as exemplified by Nigella in the Aegean Archipelago. - Philos. Trans. R. Soc. Lond. B. Biol. Sci. 27: 3083 - 3096.

Creutzburg, N. 1966. Die südägäische Inselbrücke. Bau und geologische Vergangenheit. - Erdkunde 20: 20-30.

Dermitzakis, D. 1990. The evolution of the Aegeis during the Late Cenozoic. - Geolog. Balcanica 20: 3-16.

Diamond, J. 1972. Biogeographic Kinetics: Estimation of Relaxation Times for Avifaunas of Southwest Pacific Islands. - P.N.A.S. 69: 3199 - 3203.

Dormann, C. F., Elith, J., Bacher, S., Buchmann, C., Carl, G., Carré, G., Lautenbach, S. 2013. Collinearity: A review of methods to deal with it and a simulation study evaluating their performance. - Ecography 36 : $27-46$. 
Fernández-Palacios, J. M., Rijsdijk, K. F., Norder, S. J., Otto, R., de Nascimento, L., Fernández-Lugo, S., Whittaker, R. J. 2015. Towards a glacial-sensitive model of island biogeography. - Global Eco. and Biogeo. 25: 817-830.

Georghiou, K., Delipetrou, P. 2010. Patterns and traits of the endemic plants of Greece. - Bot. J. of the Lin. Soc. 162: 130-422.

Greuter, W. 1971. L'apport de l'homme à la flore spontanée de Crête. - Boissiera 19: 329-337.

Greuter, W. 1972. The relict elements of the flora of Crete and its evolutionary significance. - In: Valentine, D.H. (ed.), Taxonomy, Phytogeography and Evolution. London \& New York: Academic Press, pp. 161-177.

Greuter, W. 1975. Die insel Kreta, eine Geo-botanische Skizze. - Insit. ETH, Stiftung, Rübel, Zurich 55: 141-197.

Greuter, W. 1979. The origins and evolution of island floras as exemplified by the Aegean Archipelago. - In Bramwell, D. (eds) Plants and islands. Academic Press, London, pp. 87-106.

Heaney, L. R., Balete, D. S., Rickart, E. A. 2013. Models of oceanic island biogeography: changing perspectives on biodiversity dynamics in archipelagoes. - Front. Biogeogr. 5:249-257.

Higgins, M., 2009. Greek Islands : Geology. - In Gillespie, R., Clague, D., (eds), Encyclopedia of Islands. University of California Press., pp. 392-396

Itescu, Y., Foufopoulos, J., Pafilis, P., Meiri , S. 2019. The diverse nature of island isolation and its effect on land bridge insular faunas. - Global Eco. and Biogeo. 29: 262-280.

Jaros, U., Tribsch, A., Comes, H. P. 2018. Diversification in continental island archipelagos: New evidence on the roles of fragmentation, colonization and gene flow on the genetic divergence of Aegean Nigella (Ranunculaceae). - Ann. Bot. 121: 241-254.

Kagiampaki, A., Triantis, K., Vardinoyiannis, K., Mylonas, M. 2011. Factors affecting plant species richness and endemism in the South Aegean (Greece). - J. Biol. Res. Thessalon. 16: 281-295.

Kallimanis, A. S., Bergmeier, E., Panitsa, M., Georghiou, K., Delipetrou, P., Dimopoulos, P. 2010. Biogeographical determinants for total and endemic species richness in a continental archipelago. - Biodiversity and Conservation 19: 1225-1235.

Kapsimalis, V., Pavlopoulos, K., Panagiotopoulos, I., Drakopoulou, P., Vandarakis, D., Sakelariou, D., Anagnostou, C. 2009. Geoarchaeological challenges in the Cyclades continental shelf (Aegean Sea). - Zeitschrift für Geomorphologie 53: 169-190.

Kougioumoutzis, K., Tiniakou, A. 2014. Ecological factors driving plant species diversity in the South Aegean Volcanic Arc and other central Aegean islands. - Plant Ecol. and Div. 8: 1755-1668.

Kougioumoutzis, K., Valli, A. T., Georgopoulou, E., Simaiakis, S. M., Triantis, K. A., Trigas, P. 2017. Network biogeography of a complex island system: the Aegean Archipelago revisited. - J. of Biogeogr. 44: 651-660.

Kreft, H., Jetz, W., Mutke, J., Kier , G., Barthlott, W. 2008. Global diversity of island floras from a macroecological perspective. - Ecology Letters 11: 116-127.

Kuznetsova, A., Brockhoff, P. B., Christensen, R. H. B. 2017. lmerTest Package: Tests in Linear Mixed Effects Models . - J of Statistical Software 82:13.

Lambeck, K., Purcell, A. 2005. Sea-level change in the Mediterranean Sea since the LGM: Model predictions for tectonically stable areas. - Quaternary Science Reviews 24: 1969-1988.

Lambeck, K., Rouby, H., Purcell, A., Sun, Y., Sambridge, M. 2014. Sea-level and global ice volumes from the Last Glacial Maximum to the Holocene. - P.N.A.S. 111: 15296-15303. 
Lewis, J. 1981. The Biology of Centipedes. - Cambridge University Press.

Médail, F. 2017. The specific vulnerability of plant biodiversity and vegetation on Mediterranean islands in the face of global change. - Regional Env. Change 17: 1775-1790.

Murtaugh, P. 2014. In defense of P values. - Ecology 95: 611-617.

Norder S.J., Proios, K.V., Whittaker, R.J., Alonso, M.R., Borges, P.A.V., Borregaard, M.K., Cowie, R.H., Florens, F.B.V., de Frias Martins, A.M., Ibáñez, M., Kissling, W.D., de Nascimento, L., Otto, R., Parent, C.E., Rigal, F., Warren, B.H., Fernández-Palacios, J.M., van Loon, E.E., Triantis, K.A., Rijsdijk, K.F. 2019. Beyond the Last Glacial Maximum: island endemism is best explained by long-lasting archipelago configurations. - Global Ecol. and Biogeog. 28: 184-197.

Norder S.J., Baumgartner, J.B., Borges, P.A.V., Hengl, T., Kissling, W.D., van Loon, E.E., Rijsdijk, K.F. 2018. A global spatially explicit database of changes in island palaeo-area and archipelago configuration during the late Quaternary. - Global Ecol. and Biogeogr., 27: 500-505.

Panitsa, M., Tzanoudakis, D. 2010. Floristic diversity on small islands and islets: Leros islets' group (East Aegean area, Greece). - Phytologia Balcanica 16: 271-284.

Panitsa, M., Trigas, P., Gregoris, I., Sfenthourakis, S. 2010. Factors affecting plant species richness and endemism on land-bridge islands - an example from the East Aegean archipelago. - Acta Oecol. 36: 431437.

Panista, M., Kagiampaki, A., Kougioumoutzis, K. 2018. Plant diversity and biogeography of the Aegean Archipelago: a new synthesis. - In: Sfenthourakis, S. (ed.), Biogeography and Biodiversity of the Aegean. Broken Hill Publishers Ltd, Nicosia, Cyprus, pp. 279-290.

Perissoratis, C. and Conispoliatis, N. 2003. The impacts of sea-level changes during latest Pleistocene and Holocene times on the morphology of the Ionian and Aegean seas (SE Alpine Europe). - Marine Geology 196: $145-156$.

Porter, S. C. 1989. Some geological implications of average Quaternary glacial conditions. - Quaternary Research 32: 245-261.

Poulakakis, N., Kapli, P., Lymberakis, P., Trichas, A., Vardinoyiannis, K., Sfenthourakis, S., Mylonas, M. 2015. A review of phylogeographic analyses of animal taxa from the Aegean and surrounding regions. - J. of Zoological Sys. and Evol. Res. 53: 18-32.

R Core Team. 2018. R: A language and environment for statistical computing. R Foundation for Statistical Computing. - Vienna Austria. URL https://www.R-project.org/.

Rechinger, K. 1943. Flora Aegaea. - Akad. Wiss. Wien. Math.-Naturwiss. Kl., Denkschr. 105:1.

Rechinger, K. and Rechinger-Moser, F. 1951. Phytogeographia Aegea. - Springer-Verlag.

Rijsdijk, K. F., Hengl, T., Norder, S. J., Otto, R., Emerson, B. C., Avila, S. P., Fernandez-Palacios, J. M. 2014. Quantifying surface-area changes of volcanic islands driven by Pleistocene sea-level cycles: Biogeographical implications for the Macaronesian archipelagos. - J. Biogeogr. 41: 1242-1254.

Runemark, H. 1969. Reproductive drift, a neglected principle in reproductive biology. - Botan. Notiser. 122: $90-129$.

Runemark, H. 1971. The phytogeography of the central Aegean. - In: Strid, A. (ed.), Evolution in the Aegean. Opera botanica, pp. 20-28

Sakellariou, D., and Galanidou, N. 2016. Pleistocene submerged landscapes and Palaeolithic archaeology in the tectonically active Aegean region. - Geological Society London, Special Publications 411: 145-178. 
Schule, W. 1993. Mammals, Vegetation and the Initial Human Settlement of the Mediterranean Islands: A Palaeoecological Approach. - J. of Biogeogr. 20: 399-412.

Simaiakis, S., Minelli, A., Mylonas, M. 2004. The centipede fauna (Chilopoda) of Crete and its satellite islands (Greece, Eastern Mediterranean) - Israel J. of Zool. 50: 367-418.

Simaiakis, S., Minelli, A., Mylonas, M. 2005. The centipede fauna (Chilopoda) of the South Aegean archipelago (Greece, Eastern Mediterranean). - Israel J. of Zool. 51: 241-307.

Simaiakis, S.M., Rijsdijk, K.F., Koene, E.F.M., Norder, S.J., Van Boxel, J.H., Stocchi, P., Hammoud, C., Kougioumoutzis, K., Georgopoulou, E., van Loon, E., Tjorve, K.M.C., Tjorve, E. 2017. Geographic changes in the Aegean Sea since the Last Glacial Maximum: Postulating biogeographic effects of sea-level rise on islands. - Paleogeography, Paleoclimatology, Paleoecology 471: 108-119.

Sondaar, P. and Van der Geer, A. 2005. Evolution and Extinction of Plio-Pleistocene Island Ungulates. Int. J. of the French Quat. Assoc. 2: 241-256.

Snogerup 1971 Evolutionary and plant geographical aspects of chasmophytic communities. - In: Davis, P. (ed.). Plant life of South West Asia. Aberdeen: Botanical Society of Edinburgh UK, pp. 157-170.

Steinbauer, M. J., Irl, S. D. H., Beierkuhnlein, C. 2013. Elevation-driven ecological isolation promotes diversification on Mediterranean islands. - Acta Oecologica 47: 52-56.

Steinbauer, M.J., Field, R., Grytnes, J.-A., Trigas, P., Ah-Peng, C., Attorre, F., Birks, H.J.B., Borges, P.A.V., Cardoso, P., Chou, C.-H., De Sanctis, M., de Sequeira, M.M., Duarte, M.C., Elias, R.B., FernandezPalacios, J.M., Gabriel, R., Gereau, R.E., Gillespie, R.G., Greimler, J., Harter, D.E.V., Huang, T.-J., Irl, S.D.H., Jeanmonod, D., Jentsch, A., Jump, A.S., Kueffer, C., Nogue, S., Otto, R., Price, J., Romeiras, M.M., Strasberg, D., Stuessy, T., Svenning, J.-C., Vetaas, O.R. and Beierkuhnlein, C. 2016, Topographydriven isolation, speciation and a global increase of endemism with elevation. Global Ecol. Biogeogr., 25: 1097-1107.

Strid,A., 1972. Some evolutionary and phytogeographical problems in the Aegean. - In: Valentine, D. (ed.). Taxonomy, Phytogeography and Evolution. Academic Press, New York, pp. 155-179.

Strid, A. 2016. Atlas of the Aegean flora. - Berlin: Botanic Garden and Botanical Museum Berlin.

Strid, A. and Tan, K. 1997. Flora Hellinica. - Koeltz Scientific Books.

Thompson, J. D. 2005. Plant evolution in the Mediterranean. - Oxford University Press.

Triantis, K.A., Mylonas, M., Weiser, M.D., Lika, K. and Vardinoyiannis, K. 2005. Species richness, environmental heterogeneity and area: a case study based on land snails in Skyros archipelago (Aegean Sea, Greece). - J. of Biogeogr. 32: 1727-1735.

Triantis, K.A., Mylonas, M., Whittaker, R.J. 2008. Evolutionary species-area curves as revealed by singleisland endemics: Insights for the inter-provincial species-area relationship. - Ecography 31: 401-407.

Triantis, K.A., Guilhaumon, F. and Whittaker, R.J. 2012, The island species-area relationship: biology and statistics. - J. of Biogeogr. 39: 215-231.

Triantis, K.A., Kougioumoutzis, K., Legakis, A., Anastasiou, I., Andriopoulos, P., Georgiadis, Ch., Lymberakis, P., Oikonomou, A., Probonas, N., Proios, K., Spaneli, V., Simaiakis, S. M., Trichas, A., Trigas, P., Vardinoyiannis, K. Sfenthourakis, S. 2018. The zoogeographic regions of the Aegean Sea: a multi-taxon approach. In: Sfenthourakis, S. (Ed.), Biogeography and Biodiversity of the Aegean. Broken Hill Publishers Ltd, Nicosia, Cyprus, pp. 279-290.

Trigas, P., Panitsa, M., Tsiftsis, S. 2013. Elevational Gradient of Vascular Plant Species Richness and Endemism in Crete - The Effect of Post-Isolation Mountain Uplift on a Continental Island System. - PLOS ONE 8: e59425. 
Valli, A.-T., Kougioumoutzis, K., Iliadou, E., Panitsa, M., Trigas, P. 2019. Determinants of alpha and beta vascular plant diversity in Mediterranean island systems: the Ionian islands, Greece. - Nordic J. of Bot. 37: $\mathrm{e} 02156$.

Veron, S., Haevermans, T., Govaerts, R., Mouchet, M., Pellens, R. 2019. Distribution and relative age of endemism across islands worldwide. - Sci. Rep. 9: 11693.

Voigtlander, K. 2011. Chilopoda - Ecology. - In: Minelli, A. (ed.), Treatise on Zoology - Anatomy, Taxonomy, Biology. The Myriapoda, Volume 1. Brill, pp.: 310-325.

Weigelt, P., Kreft, H. 2013. Quantifying island isolation - insights from global patterns of insular plant species richness. - Ecography, 36: 417-429.

Weigelt, P., Steinbauer, M.J., Cabral, J.S., Kreft, H. 2016. Late Quaternary climate change shapes island biodiversity. - Nature, 532: 99-102.

Whittaker, R. J. and Fernandez-Palacios, J. M. 2007. Island biogeography: ecology, evolution, and conservation. - Oxford University Press.

Whittaker, R. J., Triantis, K. A., Ladle, R. J. 2008. A general dynamic theory of oceanic island biogeography. - J. Biogeogr. 35: 977-994.

Whittaker, R. J., Fernandez-Palacios, J. M., Matthews, T. J., Borregaard, M. K., Triantis, K. A. 2017. Island biogeography: Taking the long view of nature's laboratories. - Science 357: 6354.

Tables.

Table 1. $\log _{10}$-transformed species area curve parameters with mean z-values (slope) and correlation coefficients. $\mathrm{S}$ is all species, $\mathrm{N}$ is native species, SIEs is single island endemics, MIEs is Multiple island endemics $(=\mathrm{PR}+\mathrm{A}), \mathrm{G}$ is Greek island endemics, $\mathrm{PE}$ is phytoregion endemics, AE is Aegean endemics.

\begin{tabular}{lllllll}
\hline Angiosperms & z-values & z-values & z-values & $\mathbf{R}^{\mathbf{2}}$ & $\mathbf{R}^{\mathbf{2}}$ & $\mathbf{R}^{\mathbf{2}}$ \\
\hline & Land-bridge islands & True Islands & Both Islands & Land-bridge islands & Land-bridge islands & True Isla \\
$\mathrm{S}$ & $0.299^{* * *}$ & $0.328^{* * *}$ & $0.329^{* * *}$ & 0.728 & 0.796 & 0.796 \\
$\mathrm{~N}$ & $0.299^{* * *}$ & $0.326^{* * *}$ & $0.331^{* * *}$ & 0.729 & 0.779 & 0.779 \\
SIEs & $0.298^{*}$ & $0.367^{* * *}$ & $0.338^{* * *}$ & 0.204 & 0.447 & 0.447 \\
MIEs & 0.187 & $0.245^{* * *}$ & $0.137^{*}$ & 0.034 & 0.290 & 0.290 \\
$\mathrm{G}$ & $0.380^{*}$ & $0.334^{* * *}$ & $0.298^{* * *}$ & 0.224 & 0.520 & 0.520 \\
$\mathrm{PE}$ & $0.253^{*}$ & $0.214^{* * *}$ & $0.136^{*}$ & 0.157 & 0.184 & 0.184 \\
$\mathrm{AE}$ & 0.131 & $0.253^{* * *}$ & $0.141^{*}$ & -0.007 & 0.330 & 0.330 \\
All-E & $0.353^{*}$ & $0.319^{* * *}$ & $0.256^{* * *}$ & 0.256 & 0.507 & 0.507 \\
Centipedes & Land-bridge islands & True Islands & Both Islands & Land-bridge islands & True Islands & True Isla \\
S & -0.034 & $0.157^{* * *}$ & $0.134^{* * *}$ & -0.109 & 0.362 & 0.362 \\
N & -0.034 & $0.176^{* * *}$ & $0.15^{* * *}$ & -0.109 & 0.368 & 0.368 \\
All-E & NA & 0.003 & 0.004 & NA & -0.022 & -0.022 \\
\hline
\end{tabular}

\section{Hosted file}

image1.emf available at https://authorea.com/users/314450/articles/444809-extreme-and-shortlasting-sea-level-stands-structure-insular-species-diversity-of-a-continental-shelf-archipelagoaegean-sea-greece

Table 2: Selected GLMM models for each chorotype with overall best performance in bold. Model performance was assessed based on AICc, BIC, $\mathrm{R}^{2} \mathrm{~m}, \mathrm{R}^{2} \mathrm{c}$ and loocv pseudo- $\mathrm{R}^{2}$. In each of these models, variables with p-values higher than 0.1 or VIF higher than 2.5 were removed. Meaning of model variables: $S$ - $A=$ 
spatial autocorrelation; prov $=$ phytogeographical province; $\log A p r=\operatorname{logarithm}$ of current area; $D p r=$ current shortest distance to the mainland; $d D m e d=$ increase in distance to the mainland compared to median sea level; $d A m e d=$ insular area loss compared to median sea level;typemed = island type (land-bridge island or true island) based on median sea level; $d D l g m=$ increase in distance to the mainland compared to LGM sea level; $d A$ lgm = insular area loss compared to LGM sea level; typelgm = island type based on LGM sea level.

Supplementary Materials

\section{Appendix 1}

In this earlier work, the Aegean archipelago was reconstructed based on a geophysical model of relative sea-level change that uses generalized sea-level equations accounting for hydro isostatic adjustments and applied on a topographic and bathymetric grid with a resolution of 30 arc-seconds (Simaiakis et al. 2017). For the median value we took a global eustatic median sea-level stand of $65 \mathrm{~m}$ below present for last nine glacial-interglacial cycles (Norder et al. 2019). We assumed that the regional geophysical effects affecting for this eustatic median sea-level stand were minimal and comparable by the post glacial sea-level rise conditions at $11 \mathrm{ka}$ BP when this sea level was achieved lastly. Islands smaller than the surface of a grid cell $\left(\sim 1 \mathrm{~km}^{2}\right)$ were excluded from the analysis, and islands separated by a distance smaller than the grid size $\left(\sim 1 \mathrm{~km}^{2}\right)$ were aggregated in the paleogeographic reconstruction to obtain a conservative estimate of the fragmentation dynamics occurring in the system (see Rijsdijk et al. 2014). All geographical data were processed in ArcGIS 10.2.2. Past and present areas and distance to the mainland were used to calculate the magnitude of geographical change caused by sea-level rise (difference between current and past values). For land-bridge islands (distance $=0$ at Median sea level or Late Glacial Maximum), the area considered is that of the island at the time step (1 Kya) preceding the connection to the mainland (see Appendix S1 in Kougioumoutzis et al. 2017).

Appendix 2Table A2.1

Current and past insular area and distance to the mainland.

\begin{tabular}{|c|c|c|c|c|}
\hline Island & Current area $\left(\mathrm{km}^{2}\right)$ & Area at MSL $\left(\mathrm{km}^{2}\right)$ & Area at LGM $\left(\mathrm{km}^{2}\right)$ & Current distance to mainland $(\mathrm{km})$ \\
\hline Agathonisi & $13 . .44$ & 36.39 & 54.13 & 17.89 \\
\hline Agios Efstratios & 42.02 & 74.41 & 233.17 & 82.98 \\
\hline Aigina & 84.22 & 210.65 & 359.54 & 6.71 \\
\hline Alatonisi & 1.83 & 1.83 & 8.97 & 53.45 \\
\hline Alimia & 7.47 & 12.47 & 105.01 & 37.44 \\
\hline Alonnisos & 113.08 & 123.85 & 372.58 & 40.82 \\
\hline Amorgos & 121.33 & 179.61 & 295.05 & 105.38 \\
\hline Anafi & 38.52 & 80.45 & 258.77 & 140.13 \\
\hline Andros & 441.78 & 734.17 & 7616.97 & 12.08 \\
\hline Antikythira & 19.68 & 34.00 & 161.09 & 59.54 \\
\hline Antimilos & 8.81 & 15.98 & 23.48 & 92.85 \\
\hline Antiparos & 61.69 & 966.62 & 7616.97 & 110.54 \\
\hline Astypalaia & 95.87 & 182.34 & 360.01 & 80.23 \\
\hline Chalki & 27.20 & 43.15 & 105.01 & 45.12 \\
\hline Chios & 843.92 & 952.13 & 952.13 & 7.07 \\
\hline Dia & 11.88 & 20.04 & 39.61 & 210.95 \\
\hline Donoussa & 13.66 & 29.05 & 7616.97 & 118.34 \\
\hline Dragonada & 2.87 & 16.35 & 31.17 & 181.96 \\
\hline Elasa & 4.04 & 6.35 & 10906.46 & 180.85 \\
\hline Fokionisi Megalo & 1.59 & 182.34 & 360.01 & 89.89 \\
\hline Folegandros & 32.35 & 54.43 & 7616.97 & 131.47 \\
\hline Gavdopoula & 1.77 & 7.58 & 358.21 & 180.94 \\
\hline
\end{tabular}




\begin{tabular}{|c|c|c|c|c|}
\hline Island & Current area $\left(\mathrm{km}^{2}\right)$ & Area at MSL $\left(\mathrm{km}^{2}\right)$ & Area at LGM $\left(\mathrm{km}^{2}\right)$ & Current distance to mainland $(\mathrm{km})$ \\
\hline Gavdos & 32.72 & 67.60 & 358.21 & 191.09 \\
\hline Gioura & 11.05 & 21.64 & 178.07 & 59.48 \\
\hline Gyali & 8.42 & 12.69 & 27.02 & 19.10 \\
\hline Gyaros & 17.55 & 34.24 & 7616.97 & 38.95 \\
\hline Ikaria & 254.68 & 327.96 & 504.25 & 50.70 \\
\hline Ios & 108.45 & 160.75 & 7616.97 & 145.01 \\
\hline Irakleia & 18.12 & 33.21 & 7616.97 & 146.01 \\
\hline Kalymnos & 248.26 & 272.57 & 293.03 & 16.49 \\
\hline Kandelioussa & 3.28 & 3.28 & 7.27 & 38.59 \\
\hline Karpathos & 393.83 & 471.05 & 831.28 & 85.15 \\
\hline Kasos & 66.71 & 149.74 & 831.28 & 140.94 \\
\hline Kastellorizo & 15.13 & 15.13 & 16.56 & 3.00 \\
\hline$K e a$ & 130.38 & 166.65 & 239.21 & 19.65 \\
\hline Keros & 15.09 & 30.34 & 7616.97 & 138.45 \\
\hline Kimolos & 48.66 & 344.91 & 710.79 & 101.07 \\
\hline Kinaros & 4.56 & 9.21 & 63.78 & 82.39 \\
\hline Kithnos & 99.43 & 138.82 & 229.74 & 37.64 \\
\hline Kos & 288.10 & 438.91 & 438.91 & 7.00 \\
\hline Koufonisi & 4.18 & 21.04 & 10906.46 & 221.47 \\
\hline Kounoupoi & 3.98 & 182.34 & 360.01 & 80.52 \\
\hline Koutsomytis & 1.51 & 182.34 & 360.01 & 82.76 \\
\hline Kriti & 8264.62 & 9208.39 & 10906.46 & 95.08 \\
\hline Kyra Panagia & 24.76 & 38.34 & 178.07 & 62.37 \\
\hline Kythira & 277.23 & 365.72 & 646.13 & 13.45 \\
\hline Leipsoi & 15.87 & 46.91 & 118.79 & 36.67 \\
\hline Lesvos & 1636.73 & 2007.52 & 2007.52 & 9.00 \\
\hline Levitha & 9.12 & 19.98 & 63.78 & 65.28 \\
\hline Limnos & 477.03 & 879.62 & 1794.26 & 58.24 \\
\hline Milos & 196.57 & 344.91 & 710.79 & 103.37 \\
\hline Mykonos & 85.80 & 144.22 & 7616.97 & 86.05 \\
\hline Naxos & 430.17 & 966.62 & 7616.97 & 120.25 \\
\hline Nisyros & 41.28 & 55.84 & 76.27 & 16.64 \\
\hline Ofidousa & 3.79 & 5.78 & 360.01 & 109.12 \\
\hline Paros & 238.19 & 966.62 & 7616.97 & 107.62 \\
\hline Patmos & 34.22 & 67.88 & 104.40 & 48.80 \\
\hline Paximada & 1.53 & 16.35 & 31.17 & 179.49 \\
\hline Polyaigos & 18.12 & 344.91 & 710.79 & 109.18 \\
\hline Pontikousa & 2.43 & 4.03 & 360.01 & 102.42 \\
\hline Psara & 40.04 & 75.04 & 173.51 & 61.27 \\
\hline Pserimos & 14.63 & 438.91 & 438.91 & 8.06 \\
\hline Rineia & 14.06 & 50.46 & 7616.97 & 83.44 \\
\hline Ro & 2.60 & 4.27 & 22.01 & 5.00 \\
\hline Rodos & 1407.68 & 1615.73 & 1982.09 & 18.03 \\
\hline Samothraki & 180.51 & 225.11 & 250.23 & 35.36 \\
\hline Schoinousa & 8.13 & 56.13 & 7616.97 & 146.82 \\
\hline Serifos & 74.09 & 102.86 & 176.48 & 62.80 \\
\hline Sifnos & 77.38 & 110.49 & 161.28 & 86.83 \\
\hline Sikinos & 41.74 & 72.12 & 7616.97 & 142.27 \\
\hline Skantzoura & 6.23 & 15.31 & 31.55 & 59.55 \\
\hline Skiathos & 47.33 & 72.32 & 72.32 & 4.12 \\
\hline
\end{tabular}




\begin{tabular}{lllll}
\hline Island & Current area $\left(\mathrm{km}^{2}\right)$ & Area at MSL $\left(\mathrm{km}^{2}\right)$ & Area at LGM $\left(\mathrm{km}^{2}\right)$ & Current distance to mainland $(\mathrm{km})$ \\
\hline Skopelos & 125.96 & 141.33 & 372.58 & 22.00 \\
Skyropoula & 6.05 & 6.29 & 38.89 & 26.17 \\
Skyros & 206.93 & 317.85 & 586.30 & 33.62 \\
Stroggyli & 3.50 & 3.50 & 4.80 & 1.41 \\
Symi & 58.00 & 102.60 & 125.78 & 8.00 \\
Syrna & 7.94 & 14.48 & 40.87 & 70.46 \\
Syros & 83.78 & 127.92 & 7616.97 & 58.82 \\
Thasos & 383.75 & 472.28 & 472.28 & 8.00 \\
Thira & 75.74 & 123.10 & 252.44 & 169.92 \\
Tilos & 61.83 & 99.55 & 134.76 & 21.02 \\
Tinos & 233.43 & 734.17 & 7616.97 & 50.93 \\
Ydra & 49.75 & 82.36 & 82.36 & 2.83 \\
Average & $\mathbf{2 2 3}$ & $\mathbf{3 2 9}$ & $\mathbf{2 1 0 4}$ & $\mathbf{7 4}$ \\
\hline
\end{tabular}

Table A2.2

Distribution of island type at Median and Late Glacial Maximum sea levels (MSL and LGM, respectively), including the islands of both the angiosperms and centipedes datasets $(\mathrm{n}=84)$.

\begin{tabular}{lll}
\hline & Sea level & Sea level \\
\hline & MSL & LGM \\
Land-bridge & 5 & 22 \\
True island & 79 & 62 \\
\hline
\end{tabular}

Appendix 3:

Species-area relationships for selected chorotypes of angiosperms on land-bridge islands and true islands. In blue dots the data points and regression lines for land-bridge islands, in green triangles the true islands. NNE stands for 'native non endemics'; EAll for 'all endemics'; AE for 'Aegean endemics'; SIEs for 'single island endemics'; GE for 'Greek endemics' and; MIEs for 'multiple island endemics'. 


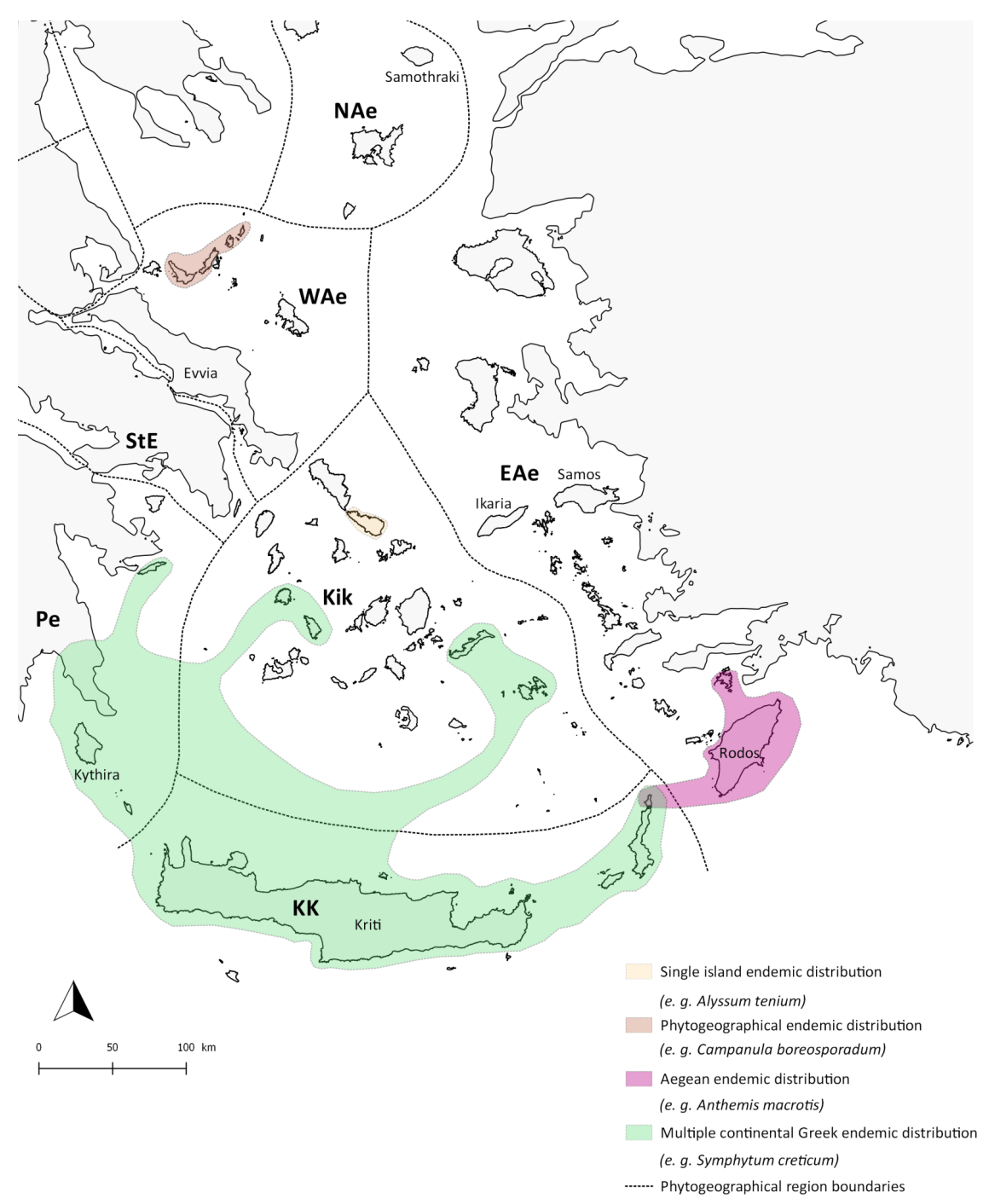




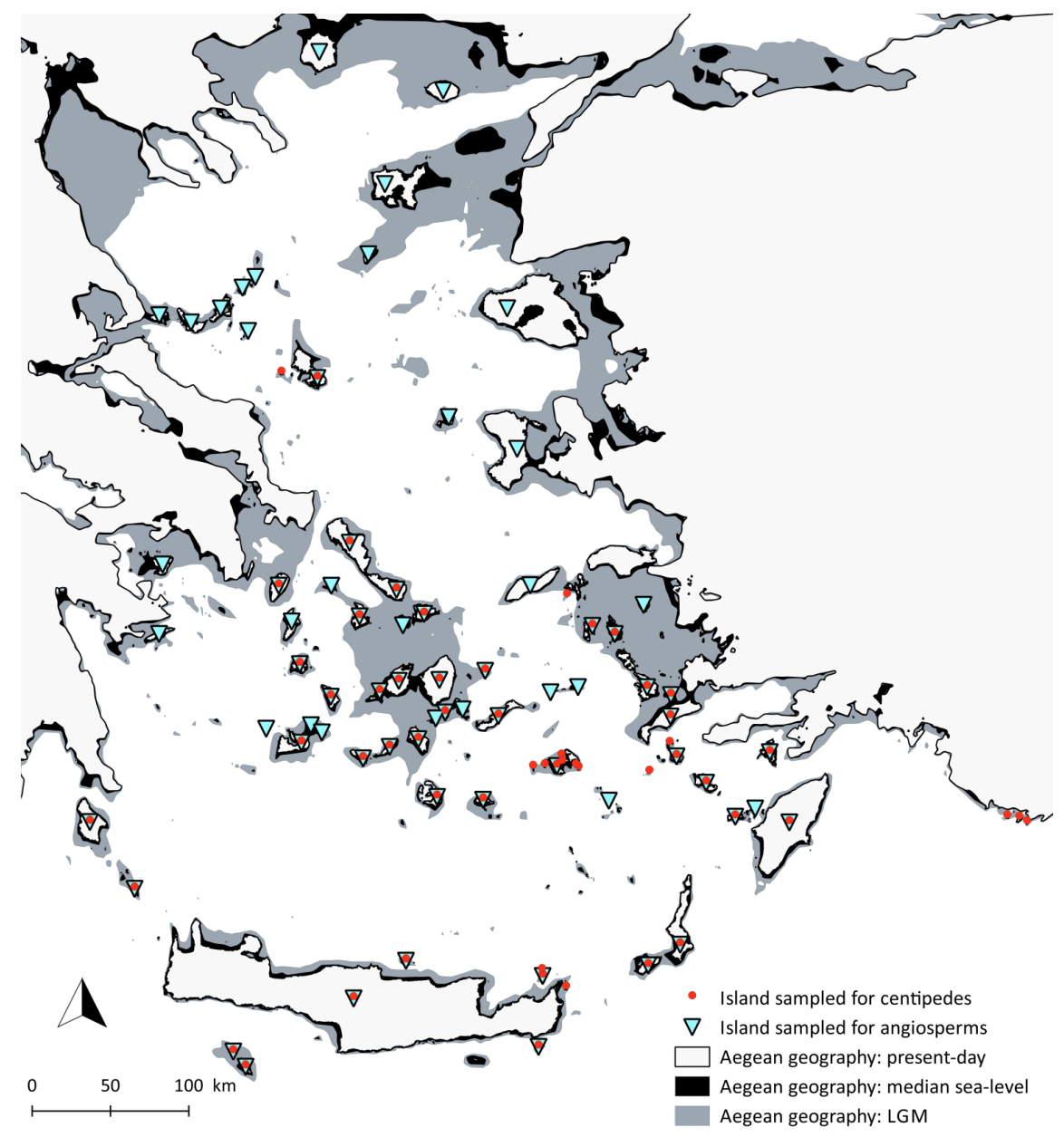



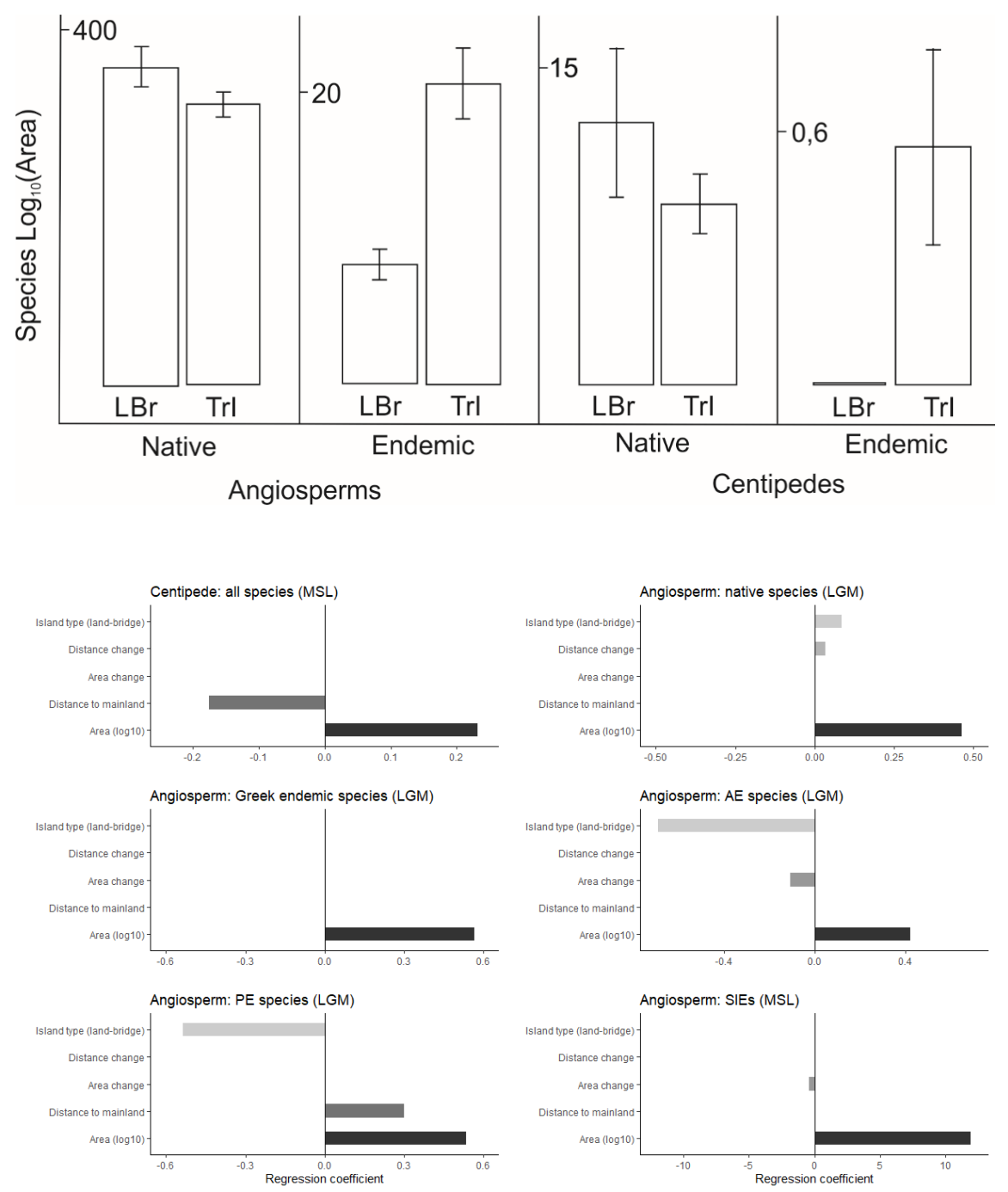